\title{
SANDBLOW SITES IN THE GREAT SANDY REGION, COASTAL SOUTHEAST QUEENSLAND: \\ implications for models of late Holocene rainforest exploitation and settlement restructuring
}

\author{
IAN McNIVEN
}

\begin{abstract}
Excavations and surface collections undertaken at four large stone artefact sites situated within huge, active parabolic dunes at Cooloola are described. I argue that these sites, along with similar sites on Fraser Island, represent elements of an Early Phase of Aboriginal use of the Great Sandy Region between at least c. 5500 to 2300 BP. Demise of the Early Phase is seen as a response to climaticallyinduced, regional decreases in rainforest distribution. This response is set within broader scale increases and decreases in rainforest exploitation seen across SE Queensland around 3000-2000 BP. The implications of complementary responses to resource restructuring in terms of reconstructions of past settlement patterns and population size are discussed.
\end{abstract}

\section{Introduction}

Archaeological research in the Cooloola region, coastal southeast Queensland has revealed an extensive archaeological record dating to the last c. 5500 years (McNiven 1985, 1990a, 1991a, 1991b, 1992a) (Figure 1). A feature of this record is a series of four stone artefact scatter sites situated within huge sandblows located adjacent to the coastline. Initial surveys suggested that these sites differed in their location, content and antiquity to shell middens located within frontal dunes along the adjacent coast (Teewah Beach) (McNiven 1984, 1985). To test these observations further, a series of excavations and surface collections was undertaken at these sandblow sites to obtain samples of artefactual remains and recover datable materials from stratified cultural deposits. This work was carried out in conjunction with a large-scale midden excavation program as part of a more general research project aimed at providing spatial and chronological insights into the nature of prehistoric Aboriginal settlement-subsistence activities at Cooloola (McNiven 1990a).

This paper presents findings of the sandblow excavations and surface collections, detailing sampling procedures, recovered remains and inferences concerning changing regional patterns of rainforest exploitation. The broader implications of these changes are set in terms of a complementary response model which posits that people may respond to regional changes in resource structure and productivity by increasing or decreasing exploitation of specific areas. Therefore, increased use of one area may be complementary to decreased use of adjacent areas. The broader application of this model to late Holocene changes in both rainforest exploitation across other parts of southeast Queensland and settlement patterns for southeastern Australia is also discussed.

\section{Great Sandy Region}

The Great Sandy Region is dominated by two large sandmasses located at Cooloola on the mainland and Fraser Island (Figure 1). Together these dune deposits form the largest coastal sandmass in the world (Report 1991 ; Sinclair 1990) with an antiquity spanning the last

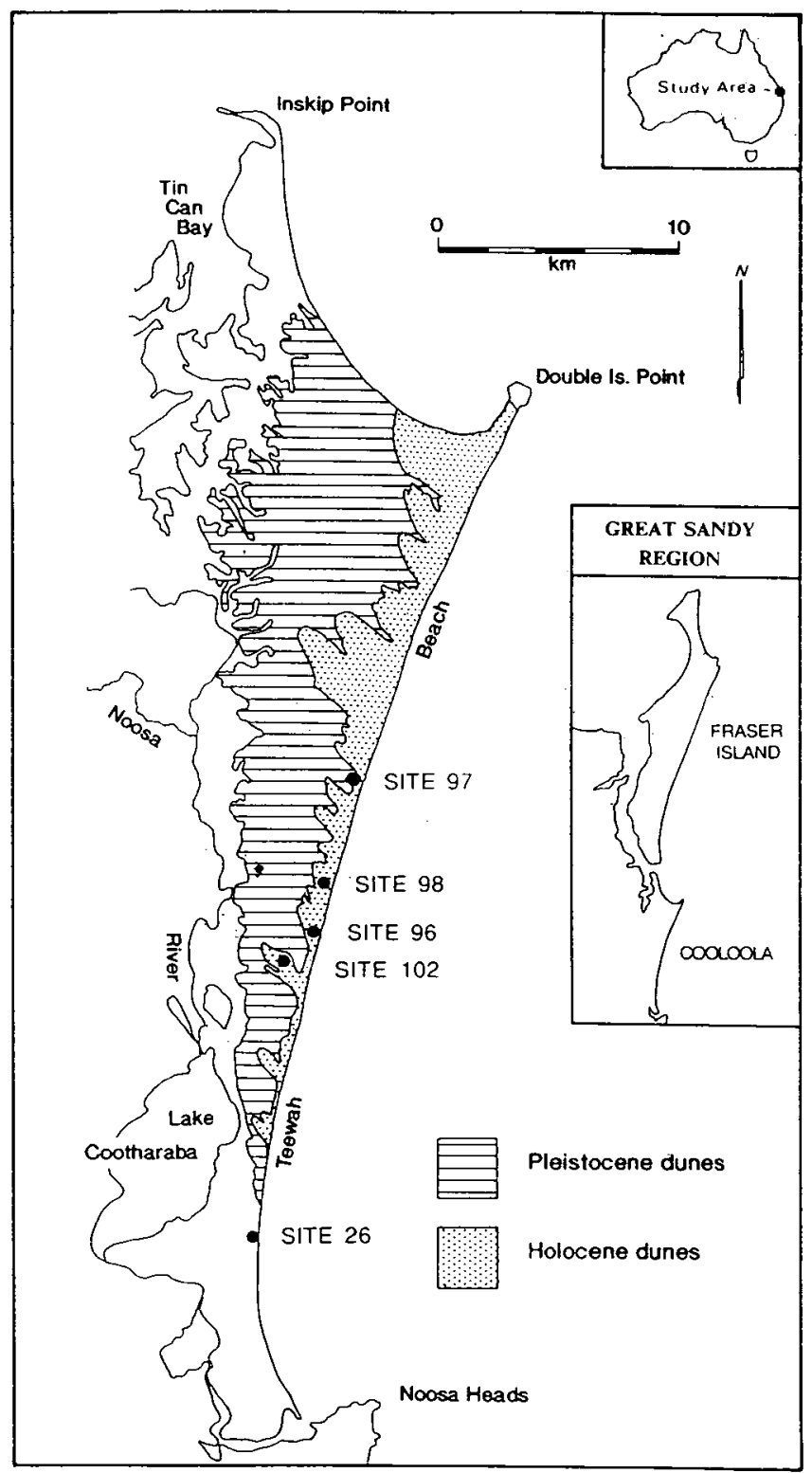

Figure 1: The study area. 
c. 730,000 TL years (Tejan-Kella et al. 1990). Recent research at Cooloola has revealed six partly exposed and overlapping dune systems extending some $10 \mathrm{~km}$ inland and achieving elevations up to $260 \mathrm{~m}$ above sea level (Thompson 1981; Thompson and Moore 1984). The dune systems are arranged in a chronosequence subparallel to Teewah Beach with Holocene Dune Systems 1-3 located closest to the coast and Pleistocene Dune Systems 4-6 located further inland across the western half of the sandmass (Figure 1).

The Great Sandy Region exhibits a complex mosaic of vegetation types (e.g. heathland, open forest, rainforest - Harrold et al. 1987; Stanton 1977). However, the central concern of this paper is a large area of subtropical rainforest covering some $100 \mathrm{~km}^{2}$ running down the centre of both Cooloola and Fraser Island (Department of Forestry 1979, 1985, 1986; Sinciair 1990; Webb and Tracey 1975). Important limiting factors for rainforest distribution are the degree of soil weathering and associated soil fertility. For Cooloola and Fraser Island, Dune System 4 and Bogimbah Dune Land respectively meet the requisite soil conditions (Stanton 1977; Thompson and Moore 1984; Walker et al. 1981; Webb and Tracey 1975).

The vegetation mosaic of Cooloola and Fraser Island has produced a highly diverse vertebrate fauna. In general, however, mammals are characterised by low total species richness, very low within-habitat diversity, low abundance and low density (Barry and Campbell 1977; Dwyer, Hockings and Willmer 1979; Dwyer, Kikkawa and Ingram 1979).

\section{Sandblow Sites}

The fous sandblow sites under discussion are King's Bore sandblow Site 97, White Cliffs sandblow Site 98, Fern Gully sandblow Site 96 and Cooloola Sand Patch Site 102 (Figure 1). Details of excavations and surface collections follow.

\section{Kang's Fore Sandblow Site 97}

King's Bore sandblow is located $40-100 \mathrm{~m}$ a.s.l. commencing some $250 \mathrm{~m}$ inland from Teewah Beach (Figures 1 and 2). It has a maximum length and width of approximately $700 \mathrm{~m}$ and $300 \mathrm{~m}$ respectively. The eastern half of the sandblow exhibits a large (c. $50 \mathrm{~m} \times 200 \mathrm{~m}$ ) stone artefact scatter concentrated along the central dune floor (Figure 3).

\section{Dure floor surface collections and excavations}

The eastern half of the site was characterised initially in 1983 using a systematic series of eleven $1 \mathrm{~m}^{2}$ surface collection squares (Squares A-K) spaced $10 \mathrm{~m}$ apart along a 110m-long transect (McNiven 1985:15) (Figures 3 and 4). All cultural remains were recovered within $5 \mathrm{~cm}$ of the surface. A subsequent series of 12 collection circles was established to the northwest (Circles 1-11) and southeast (Circle 12) of the surface collection transect in 1987 (Figure 3). Circles 1-11 were placed at $8 \mathrm{~m}$ intervals along a zig-zag transect and had areas of either $4 \mathrm{~m}^{2}$
(Circles 1-5) or $10 \mathrm{~m}^{2}$ (Circles 6-11). Circle $12\left(20 \mathrm{~m}^{2}\right.$ ) was located adjacent to Square $A$. The contents of Circles 1-12 were excavated using a single Excavation Unit $(X U)$ with a maximum depth of $5 \mathrm{~cm}$ and dry sieved through $3 \mathrm{~mm}$ mesh. All cultural remains were recovered from loose sandy sediments lying above compacted dune sediments.

A total of $1.22 \mathrm{~g}$ of shellfish and fish remains was recovered. Based on their good preservation and the nature of recent dingo and raptor food remains on the site, I argue that all of these remains probably derive from the activities of carnivores (McNiven 1990b).

A total of 5254 stone artefacts weighing $5264.6 \mathrm{~g}$ was recovered, of which $41 \%$ exhibit flaking (flakes, flaked pieces, retouched flakes and cores - see Hiscock 1984:129 for definitions) and the remainder are manuports (i.e. transported stones showing no signs of human modification). At least 10 raw material types are represented, the most numerous being quartz $(65.9 \%)$, silcrete $(22.8 \%)$, andesite $(3.1 \%)$, arkose (feldspathic sandstone) $(2.8 \%)$ and chert $(2.2 \%)$. Most quartz artefacts, however, are small pebble manuports weighing less than $0.2 \mathrm{~g}$ and appear to "represent the more resistant and less weathered remains of sandstone (conglomerate) artefacts whose softer matrix has been eroded away" by sandblasting (McNiven 1985:23). Discounting these manuports, it is clear that the majority of flaked artefacts are silcrete $(\mathrm{n}=1192,55.0 \%)$.

A variety of formal implement types including 16 backed blades, six bifacial points, six bevel-edged tools (cf. bevelled pounders - see Gillieson and Hall 1982; Kamminga 1981) and a single anvil were recovered from the collection units or as isolated finds from other sections of the dune floor. Most backed blades were manufactured from chert $(n=11)$ and had a maximum length range of $8 \mathrm{~mm}$ to $50 \mathrm{~mm}$ (Figure 5a-d). Bifacial points were made from either silcrete, andesite or chert and ranged in length from $19 \mathrm{~mm}$ to $72 \mathrm{~mm}$ (Figure 6). Bevel-edged tools are made from either sandstone (including arkose) or silcrete and exhibit bevels up to $70 \mathrm{~mm}$ long and $14 \mathrm{~mm}$ wide (Figure $7 \mathrm{a}$ ). The split arkose cobble anvil exhibits a series of small impact pits, and was possibly used in association with bipolar cores recovered from the site (Figure $7 \mathrm{~b}$ ).

\section{Dure apex excavation}

It was clear from the highly unstable and active dune floor that the original stratigraphic context of exposed artefacts had long since blown away. I speculated, therefore, that remnant in-situ deposits may exist towards the front of the sandblow half-way up the steep internal sides of the dune apex given the restriction of stone artefacts to below this level. Similarly, the degree of sandblasting on artefacts was less pronounced in this area suggesting recent erosion from a buried deposit. Subsequent examination of the dune apex with a shovel resulted in the location of an in-situ stone artefact some $16 \mathrm{~mm}$ vertically below the top of the dune erosion slope. A controlled excavation was consequently undertaken at 


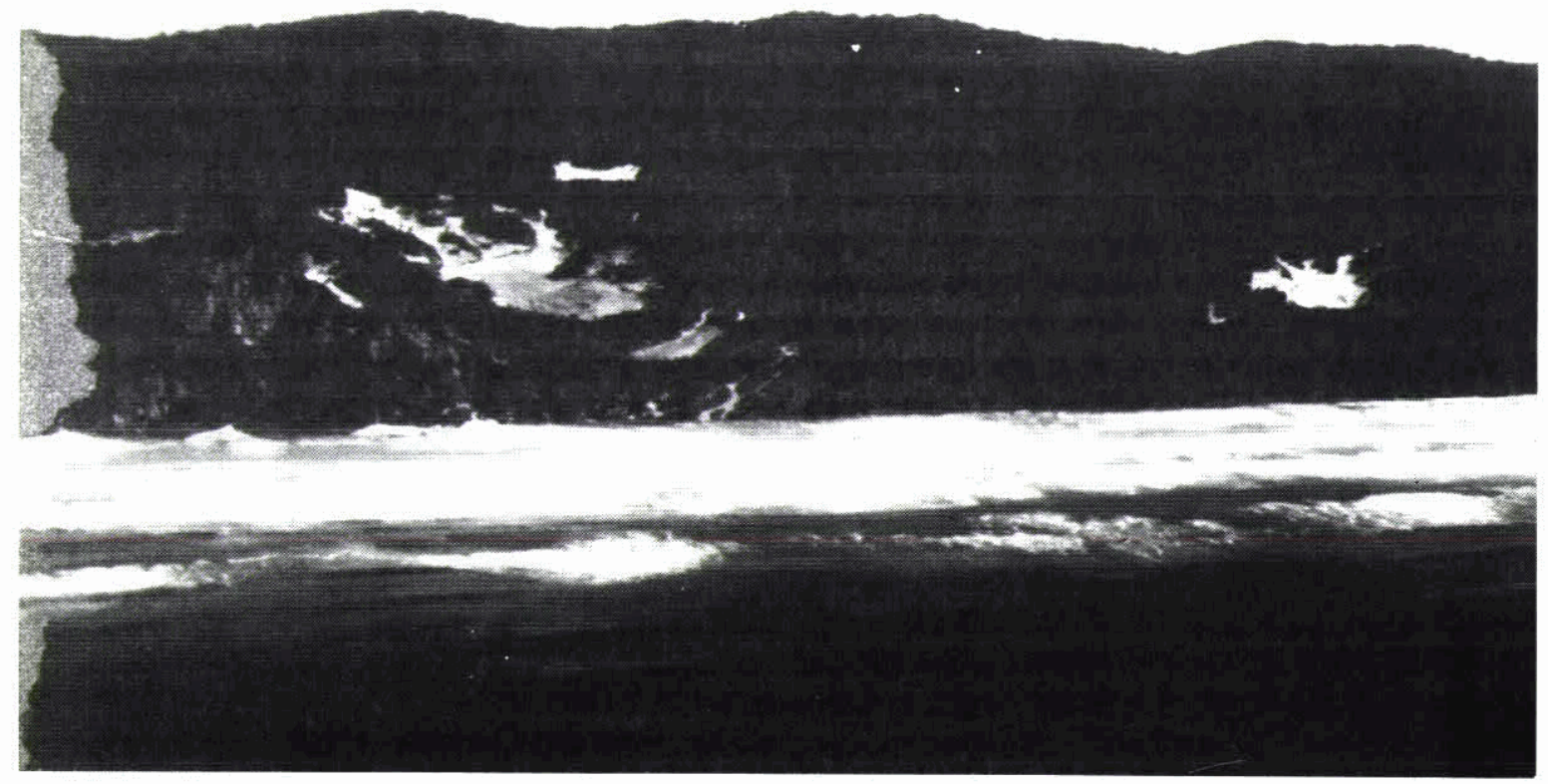

Figure 2: King's Bore Sandblow Site 97 seen from the sea.

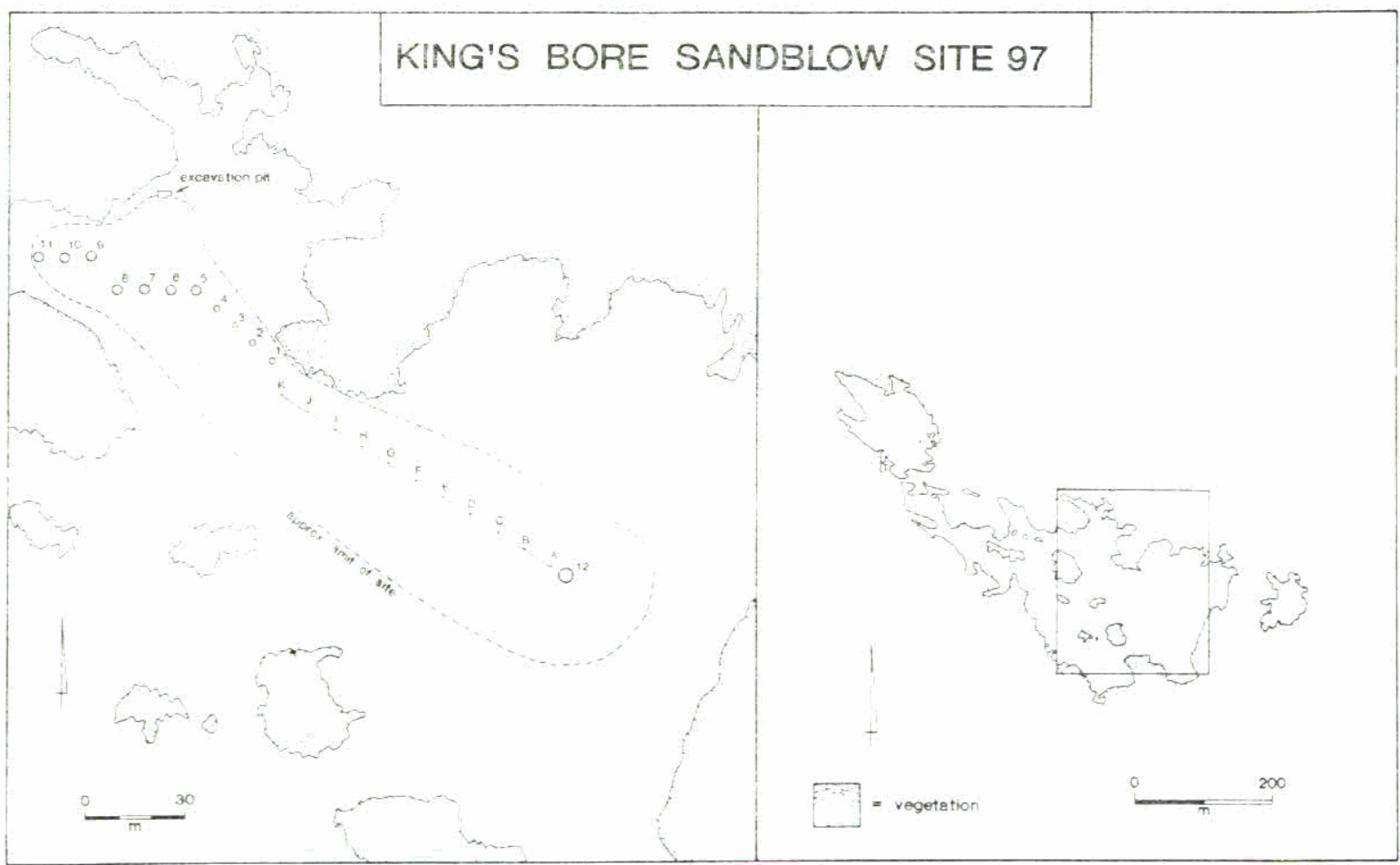

Figure 3: Site plan of King's Bore sandblow Site 97 showing location of surface collections (Squares A-K) and excavations (Circles 1-12, and pit). 


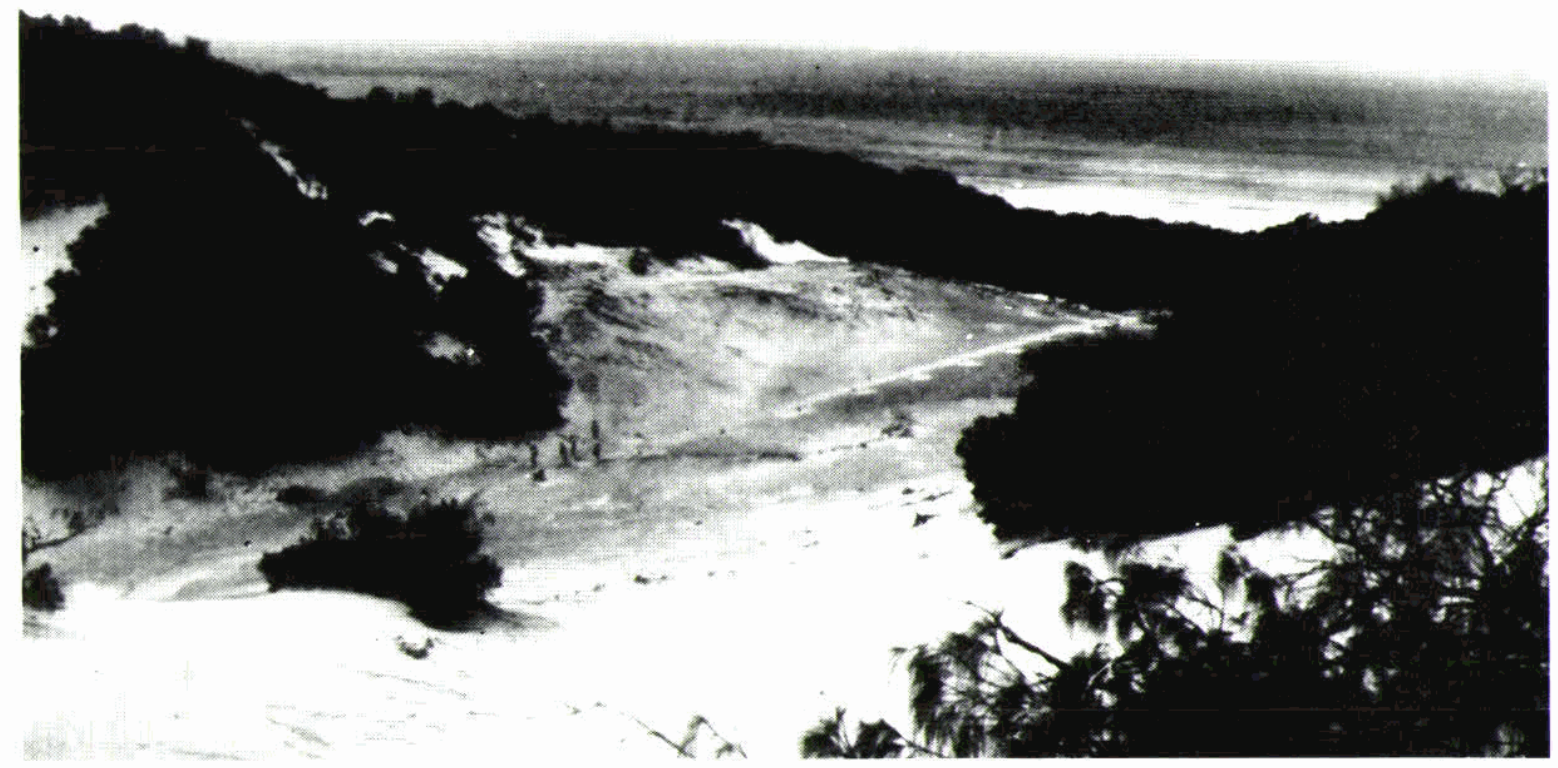

Figure 4: General view looking northeast across the eastem half of King's Bore Sandblow Site 97 during surface collection of artefacts in 1983.

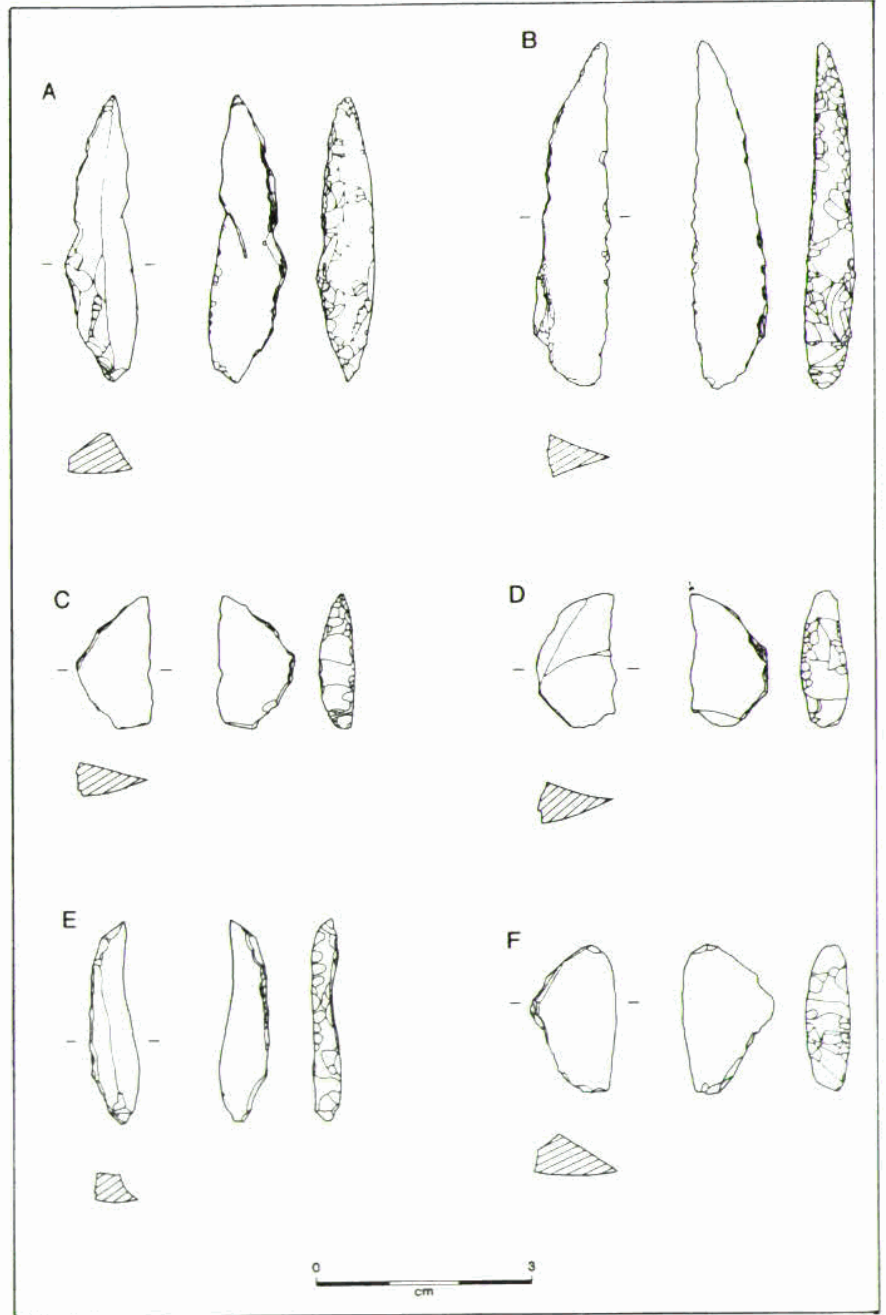

Figure 5: Backed blades from sandblow sites (A: 97/IF12, B: 97/IF23, C: 97/IF1, D: 97/IF7, E: 102/IF11, F: $98 / 1 / 1$
A
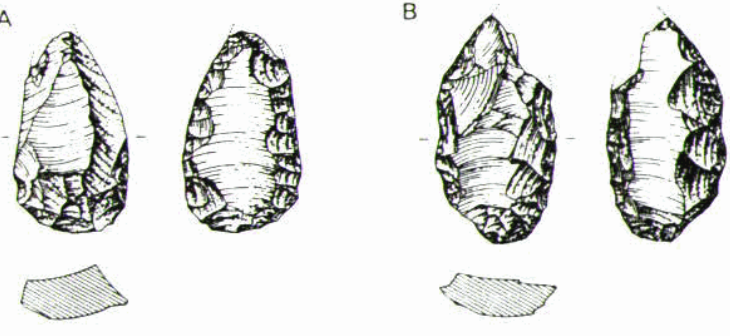

C
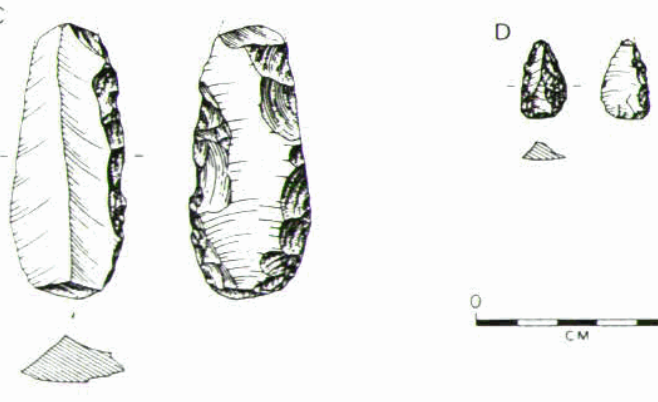

$\triangle$

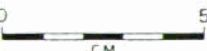

Figure 6: Bifacial points from King's Bore Sandblow Site 97 (A: 97/IF9, B: 97/IF11, C: 97/IF8, D: 97/9/1). 
A
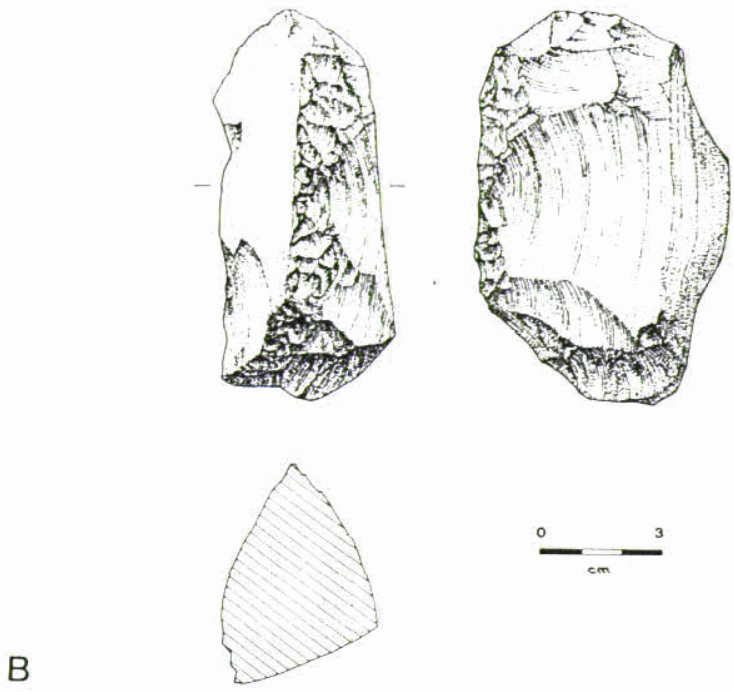

B

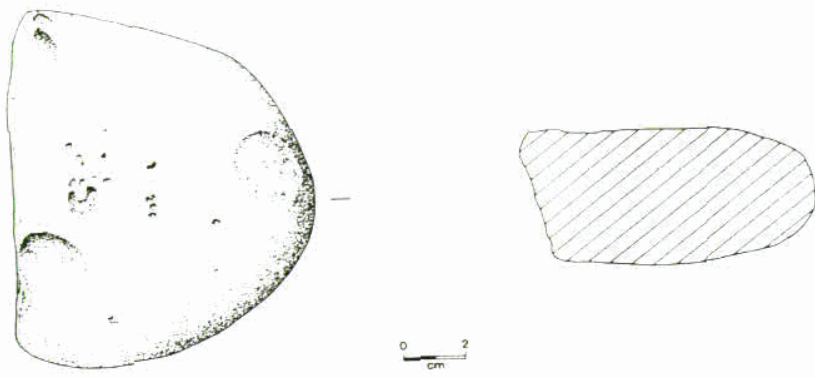

Figure 7: Selected artefacts from King's Bore sandblow Site 97 (A: bevel-edged tool [IF18], B: anvil [[F21]).

this point to first, characterise and date the apparent cultural layer and, second, test whether remains of the original stratigraphic context of dune floor artefacts had been discovered (Figure 8 ).
An alphanumeric $1 \mathrm{~m} \times 1 \mathrm{~m}$ grid (aligned $346^{\circ}$ - magnetic) was established and 10 contiguous Grid Units (GUs J1O, $\mathrm{J11}, \mathrm{J12}, \mathrm{J13}, \mathrm{K} 1 \mathrm{O}, \mathrm{K} 11, \mathrm{~K} 12, \mathrm{~K} 13, \mathrm{~L} 10$ and $\mathrm{L} 11$ ) forming a large sub-rectangular-shaped pit was excavated on the steep (c. $25^{9}$ ) slope. The pit was dug to a maximum depth of $184 \mathrm{~cm}$ and a total of 74 XUs representing $8057.5 \mathrm{~kg}$ of material was excavated.

Five major Stratigraphic Units (SU) were identified (Figure 9). SUl covers the deposit towards the rear of the trench and consists of very pale brown (10YR-7/4) to brown (10YR-5/3) loose sand with a $\mathrm{pH}$ ranging from 6.0 to 7.0. Unlike the in-situ dune deposit making up the reminder of the sequence, the sediment in this unit appeared to be recent disturbed avalanche material deriving from further up the slope. $S U 2$ has a mean thickness of c. $20-25 \mathrm{~cm}$ and consists of light yellowish brown (10YR-6/4) to brown (10YR-5/3) loose sand with numerous charcoal fragments and a $\mathrm{pH}$ of 6.5 .

$S U 3$ consists of very pale brown (10YR-7/3) to light yellowish brown (10YR-6/4) loose sand with a mean thickness of c. $20 \mathrm{~cm}$. It exhibits a $\mathrm{pH}$ ranging from 6.5 to 7.0. SU4 grades from light brownish gray (1OYR-6/2) to brown (10YR-5/3) loose sand with depth. It has a mean thickness of c. $30 \mathrm{~cm}$ and a pH value of mostly 7.0 . Patches of very light gray sand across the lower half of the unit appear to represent variations in soil podzolization. The bulk of stone artefacts was recovered from the lower half of this unit. SUS represents a major change in the deposit from brown-dominated sands (SUs $1-4)$ to gray-dominated sands. The unit is highly mottled and ranges from light brownish gray (10YR-6/2) to dark gray $(10 \mathrm{YR}-4 / 1)$ loose sand with a $\mathrm{pH}$ of $6.5-7.0$.

The brown-dominated sands in SUs 1-4 show only minor podzolization consistent with Holocene Dune Systems 1-3. In contrast, the gray-dominated sands of

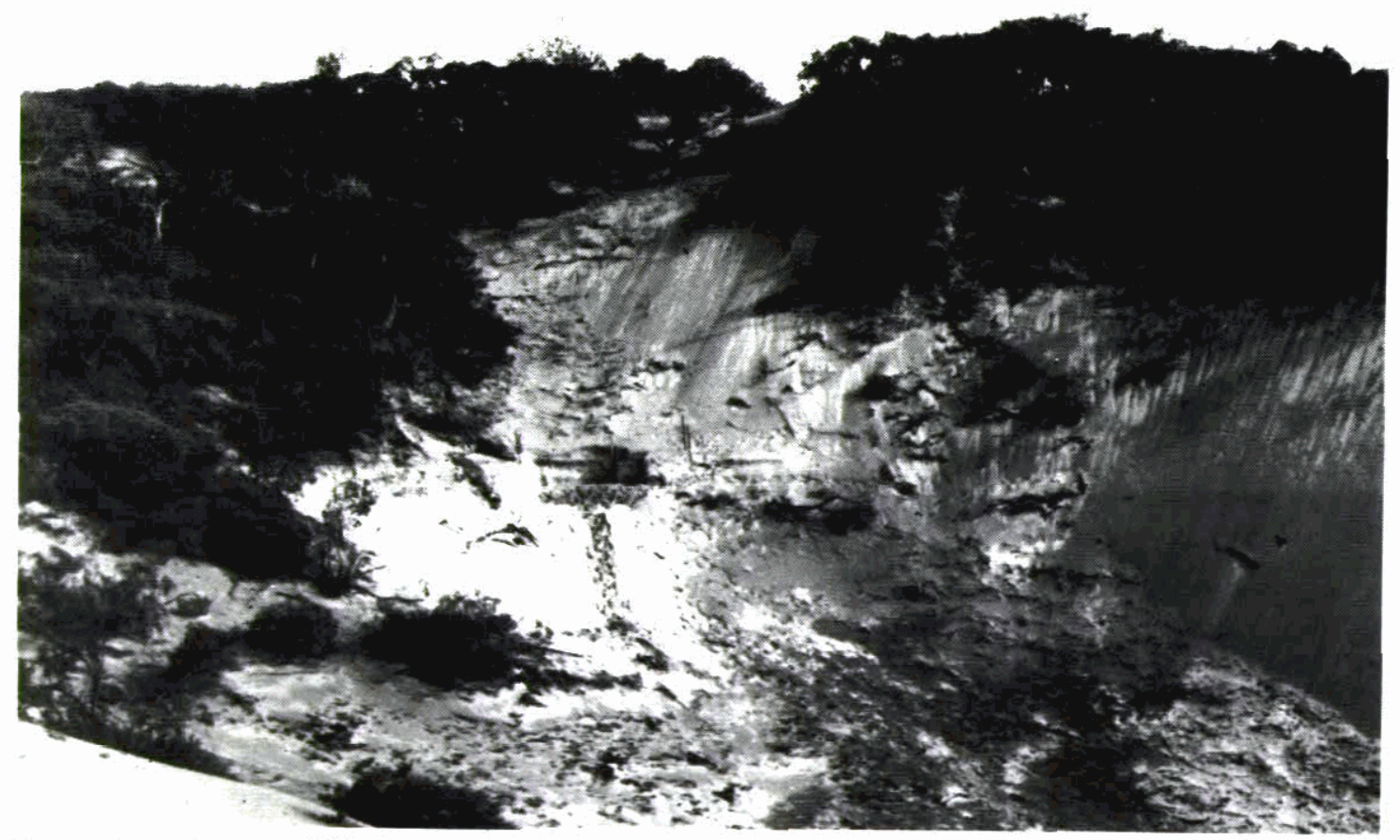

Figure 8: Excavation pit set within steep erosion face of dune apex at King's Bore Sandblow Site 97 . The pit is situated at the interface of Holocene and Pleistocene sands located at a depth of $16 \mathrm{~m}$ below the current dune top. 


\section{KING'S BORE SANDBLOW SITE 97 DUNE APEX EXCAVATION \\ Stratigraphic section}

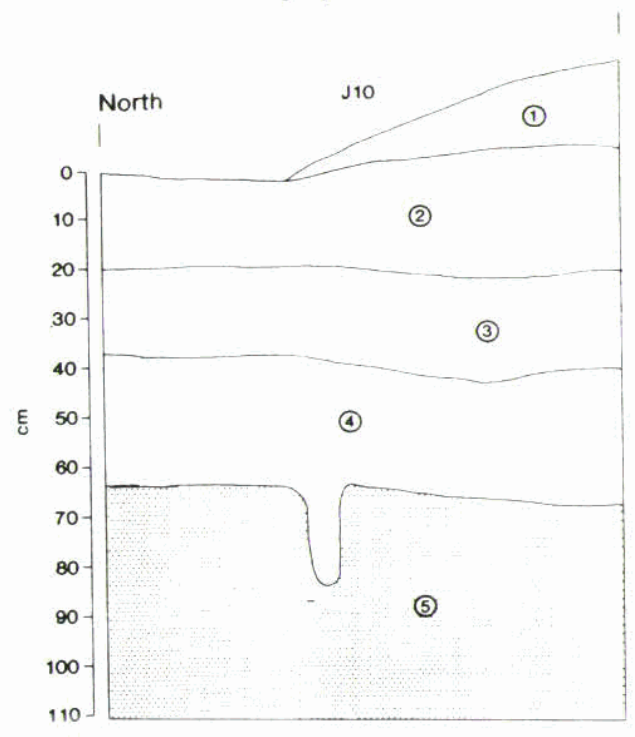

Figure 9: Stratigraphic section for dune apex excavation, King's Bore sandblow Site 97.

SU5 are more consistent with the A soil horizon of a Pleistocene dune (cf. Dune System 4). The mixture of brown and gray sands in SU4 probably occurred during the advancement of Holocene sands across the surface of the old Pleistocene dune $(\mathrm{C}$. Thompson, CSIRO Division of Soils, Brisbane, pers. comm. 1988).

Two radiocarbon age determinations were obtained on good quality wood charcoal. The first date was obtained from XU8 (GU:J12) and is associated with the major concentration of stone artefacts in the lower $10 \mathrm{~cm}$ of SU4 (Figure 10). It produced a calibrated date of $2332 \mathrm{BP}$ (Table 1). The second radiocarbon date was obtained from XU7 (GU:J10b) spanning the lower $5 \mathrm{~cm}$ of SU4 and the upper $15 \mathrm{~cm}$ of SU5 to provide a maximum age for the major stone artefact concentration. It produced a calibrated date of $3833 \mathrm{BP}$ (Table 1). As a result, I infer that the main stone artefact concentration was deposited some time between c. 3800-2300 cal BP.

The mid-Holocene date of the in-situ stone artefact layer contrasts greatly with a thermoluminescence date of $19,000 \pm 200$ obtained on sand grains from the overlying dune (Tejan-Kella et al. 1990). It is clear that the TL date is in gross error, probably resulting from incomplete zeroing of the sands during dune formation (Tejan-Kella et al. 1990:478).

A total of $1.37 \mathrm{~g}$ of shellfish and fish bone and scale fragments was recovered from surface avalanche sediments in SU1. No faunal remains were found in association with SUs 2-5. Following inferences concerning the origins of dune floor faunal remains, it is clear that all faunal items from SUI derive from the activities of carnivores (McNiven 1990b)
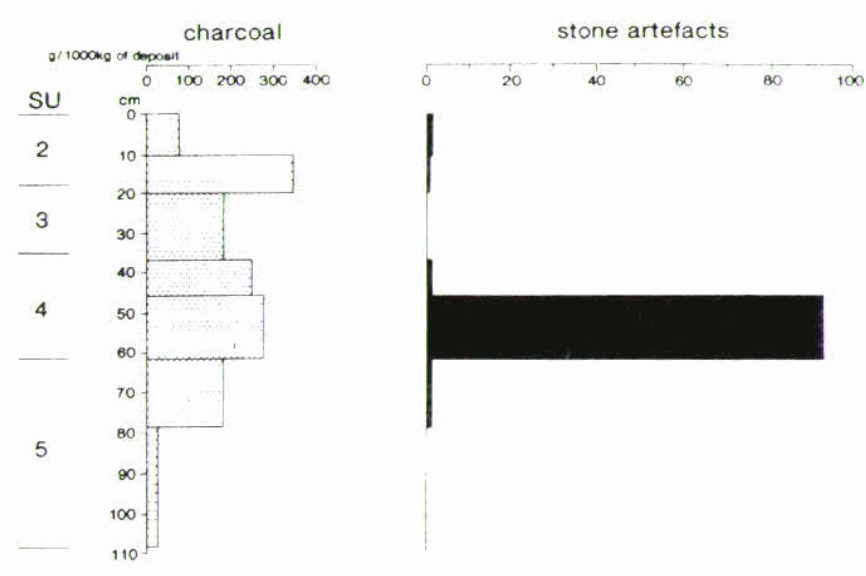

Figure 10: Vertical distribution of excavated finds from dune apex unit, King's Bore sandblow Site 97 (NB: arbitrany depth values).

Some 143 stone artefacts weighing $137.5 \mathrm{~g}$ were the only cultural remains recovered. Most $(97.2 \%)$ consist of flaked stone artefacts, none of which exhibit retouching. The most numerous raw material types were silcrete $(25.9 \%)$, arkose $(21.0 \%)$, chert $(21.0 \%)$ and quartz $(19.6 \%)$. This pattern is similar for flaked stone artefacts from the dune floor with silcrete the most significant raw material followed by arkose, chert and quartz (albeit in differing proportions). The main exception is andesite, which was not recovered from the excavation pit.

The lack of retouched flakes may be a result of small sample size. For example, retouched flakes represented only $0.9 \%$ of dune floor flaked artefacts. If a similar proportion of retouching existed for dune apex artefacts, only 1.3 retouched flakes should have been recovered. The fact that none were recovered is consistent with the sampling error hypothesis.

Although no formal implement types were excavated from the dune apex, a fragment of a silcrete bevel-edged tool was recovered from the erosion slope less than $2 \mathrm{~m}$ from the pit (Figure 11). It exhibited no signs of sandblasting and had obviously eroded from in-situ sediments immediately prior to my excavations. The recovery of this tool is consistent with finds from the dune floor

Five major conclusions are drawn from the dune apex excavations. First, it is doubtful that the in-situ cultural layer represents a deflation deposit due to the absence of sandblasting damage on associated stone artefacts. Second, the low number of dune apex manuports concurs with the sandblasting hypothesis associated with exposed dune floor pebble manuports. Third, the absence of faunal remains within the in-situ cultural layer is consistent with the absence of faunal remains of cultural origin on the dune floor. Fourth, the in-situ cultural layer is probably the remains of the original stratigraphic context of dune floor stone artefacts. Fifth, the site has a probable antiquity of somewhere between c.3800-2300 cal BP. 
TABLE 1: Radiocarbon age deteminations for King's Bore sandblow Site 97

\begin{tabular}{||l|l|l|l|l|l|}
\hline Lab. No. & GU-XU & $\begin{array}{l}\text { Max. depth } \\
\text { range below } \\
\text { datum (cm) }\end{array}$ & $\begin{array}{l}\text { C-14 age } \\
\text { (yrs bp) }\end{array}$ & $\begin{array}{l}\text { Cal age } \\
\text { (yrs BP) }\end{array}$ & Cal age (2 sigma) \\
\hline Beta-30402 & J12-8 & $81-93$ & $2290 \pm 80$ & 2332 & $2460-2066$ \\
\hline Beta-25510 & J10b-7 & $87-107$ & $3560 \pm 100$ & $3833^{*}$ & $4146-3569$ \\
\hline
\end{tabular}

= one of three calibrated dates $(38 \overline{33}, \overline{3787}, \overline{3784})$

NB: Dates calibrated using CALIB (Rev.2.0) computer program (Struiver and Reimer 1986). Calibrated dates chosen represent those closest to the midpoint of the 2 sigma calibrated age range.
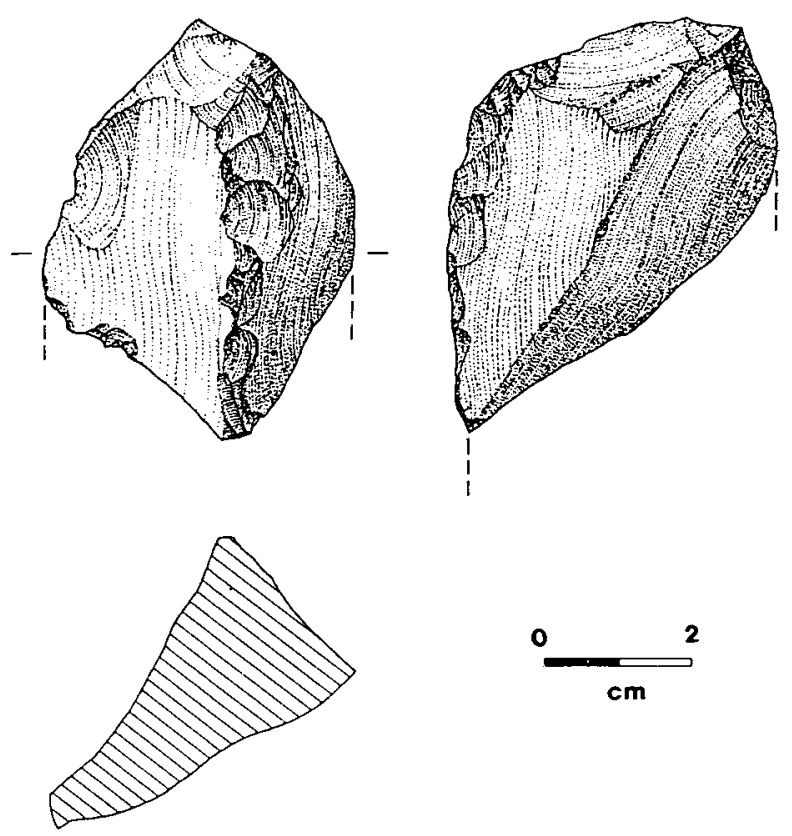

Figure 11: Bevel-edged tool fragment recovered dune slope from adjacent to excavation pit at King's Bore Sandblow Site 97 (scale in $\mathrm{cm}$ units)

\section{White Cliffs Sandblow Site 98}

White Cliffs sandblow Site 98 is located approximately $100 \mathrm{~m}$ a.s.l. immediately inland from a huge sandcliff flanking Teewah Beach (Figure 1). The site exhibits two surface concentrations of stone artefacts across the southeast of the sandblow spread over an area of at least 500-600 $\mathrm{m}^{2}$ (Figure 12). All artefacts appear to represent "lag gravel" deposits resulting from wind deflation of older dune sediments (see Thompson and Moore 1984:79)

A sample of stone artefacts was obtained from each concentration using two $10 \mathrm{~m}^{2}$ collection circles. Each circle was excavated down to a maximum depth of $5 \mathrm{~cm}$ using a single $\mathrm{XU}$. All stone artefacts were recovered from the surface within a matrix of loose light brown Holocene sand. The only stratigraphic change was observed in Circle 2 which exhibited light gray podzol sands of Pleistocene age (cf. Dune System 4) beneath the surface cultural layer. Stone artefacts were the only cultural remains recovered and no radiocarbon dates were obtained.

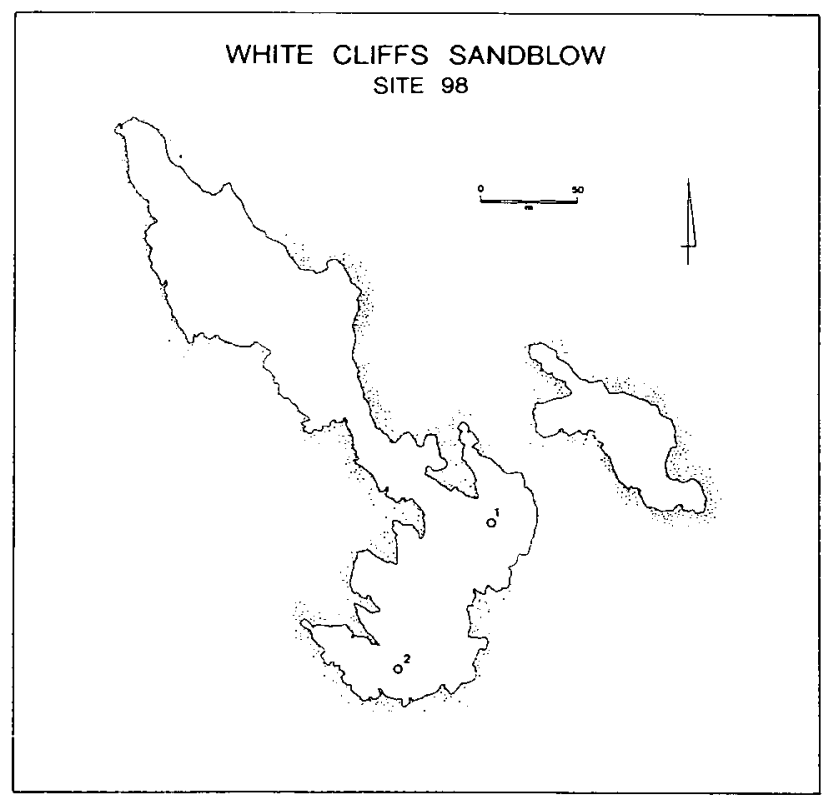

Figure 12: White Cliffs Sandblow Site 98 showing location of Circles 1 and 2.

A total of 37 stone artefacts weighing $1217.8 \mathrm{~g}$ was recovered. Most ( $97.3 \%)$ were either flakes, flaked pieces or cores. Silcrete $(56.8 \%)$ and arkose $(24.3 \%)$ are the most numerous raw material types. The only formal implement type was a silcrete backed blade (Figure 5f), while two sandstone anvils with impact pits (e.g. Figure 13a) and an arkose hammerstone with a large area of impact pitting at one end (Figure 13b) were surface collected as isolated finds from other parts of the site.

\section{Cooloola Sand Patch Site 102}

The Cooloola Sand Patch commences $0.5 \mathrm{~km}$ inland from Teewah Beach and extends for $2.3 \mathrm{~km}$ to the northwest with a maximum width of $1.1 \mathrm{~km}$ (Figures 1,14 ). It ranges in elevation from c. $100 \mathrm{~m}$ to $230 \mathrm{~m}$ a.s.l. A discontinuous scatter of stone artefacts is located across the eastern half of the sandblow. As observed at Sites 97 and 98 , all these stone artefacts appear to represent lag deposits resulting from wind deflation of older dune sediments. Although time restrictions precluded detailed site mapping, artefacts were observed over an area of at least $2000-3000 \mathrm{~m}^{2}$. 
A
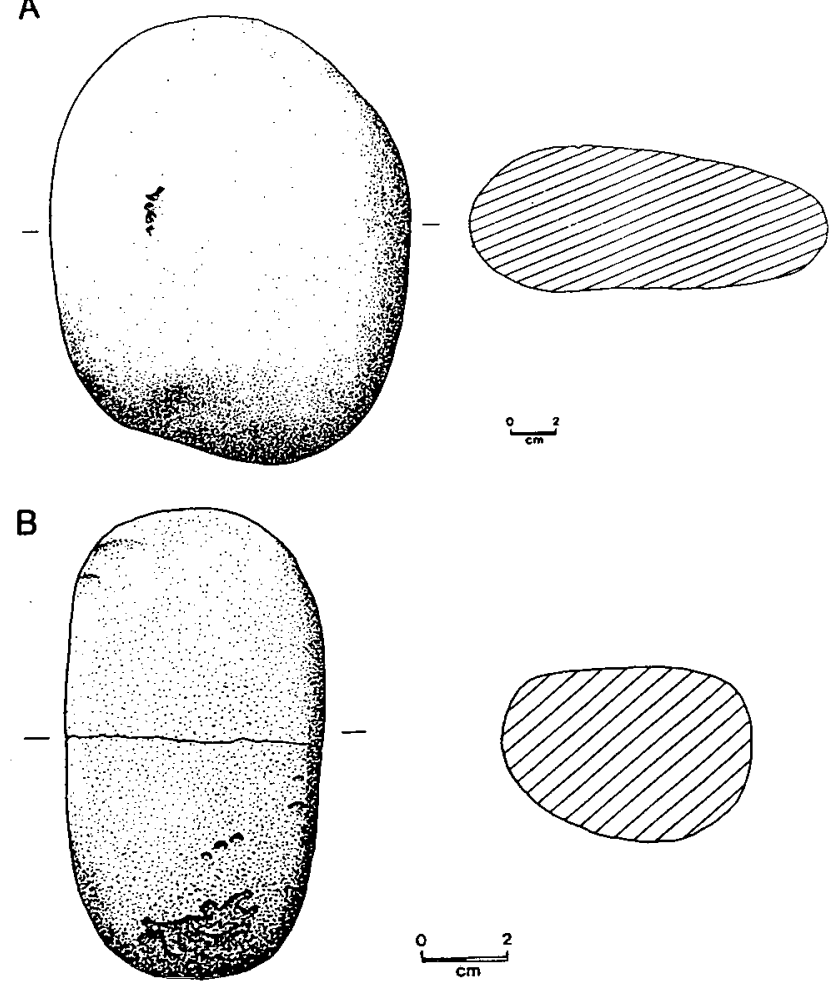

Figure 13: Selected artefacts from White Cliffs sandblow Site 98 (A: anvil [IF1], B: hammerstone [IFs 2 and 3]).
A large stone artefact scatter located along the central northern part of the sandblow was excavated using a systematic series of four $10 \mathrm{~m}^{2}$ circles (Circles 1-4) spaced at $8 \mathrm{~m}$ intervals along a transect (Figure 14). Cultural remains within each circle were excavated using a single XU with a maximum depth of $5 \mathrm{~cm}$. The sediment consisted of loose, light gray giant podzol sand of Pleistocene age (cf. Dune System 4). No stratigraphic changes were observed and all stone artefacts were recovered from the surface. Stone artefacts were the only cultural remains recovered and no radiocarbon dates were obtained.

A total of 215 stone artefacts weighing $1444.1 \mathrm{~g}$ was recovered. Flaked artefacts made up the entire assemblage (e.g. flakes, flaked pieces, retouched flakes and cores) and no formal implement types were recorded. Quartz $(49.8 \%)$ and silcrete $(37.7 \%)$ are the most numerous raw materials.

A number of formal implement types were recorded as isolated finds from other parts of the site. They include an arkose anvil with numerous impact pits across one side (Figure 15), a sandstone bevel-edged tool with a massive $16 \mathrm{~mm}$-wide bevel and two chert backed blades (e.g. Figure 5e).

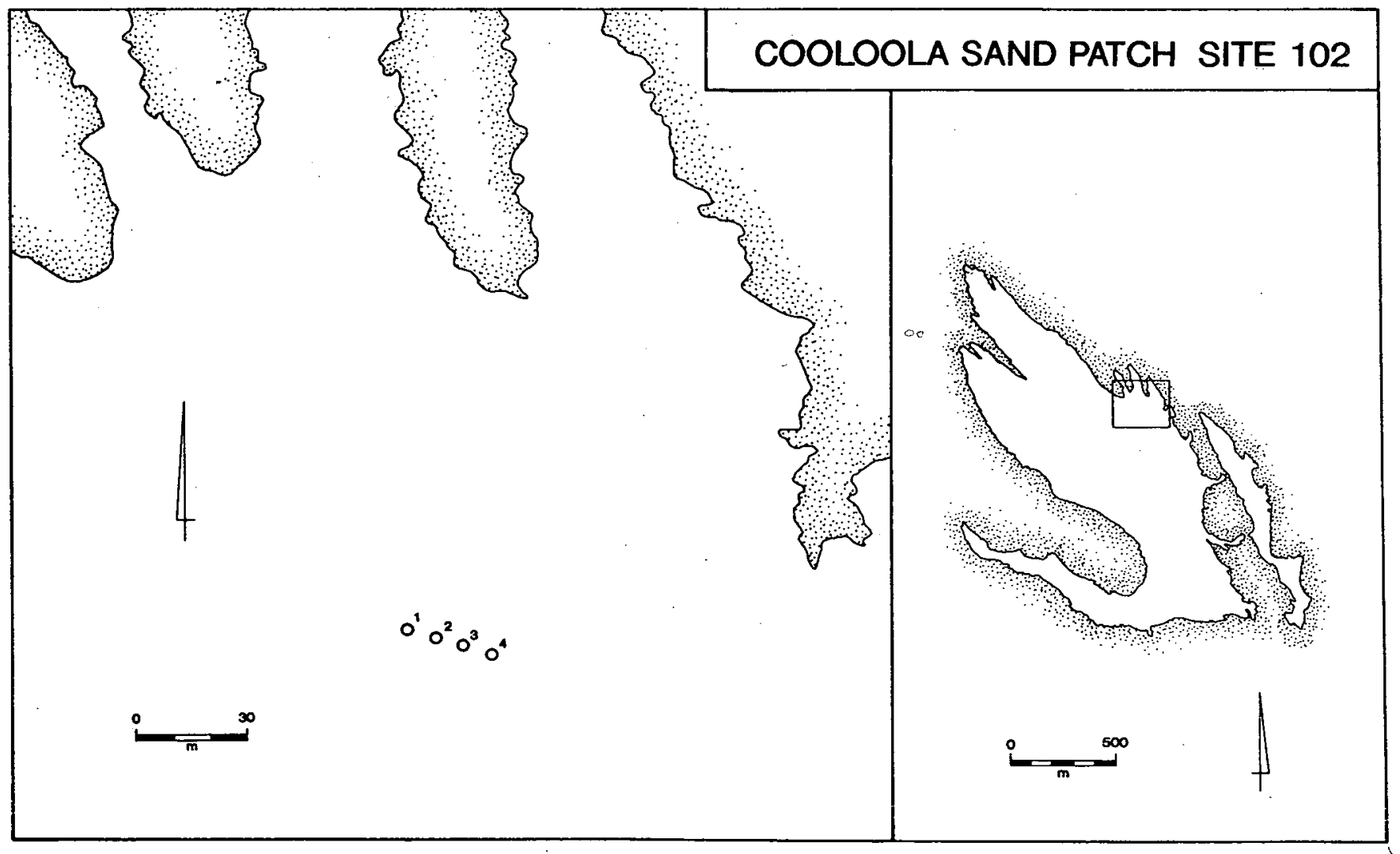

Fgure 14: Cooloola Sand Patch Site 102 showing location of Circles 1-4. 


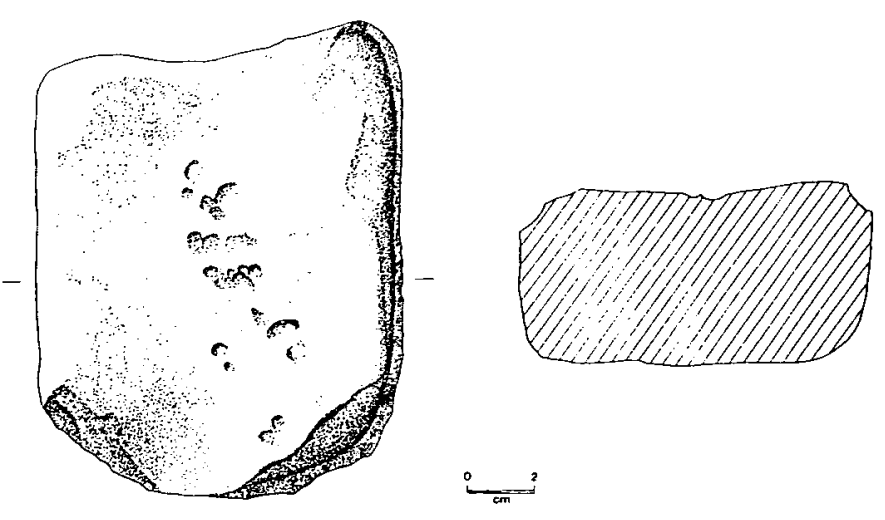

Figure 15: Anvil from Cooloola Sand Patch Site 102 (IF7).

\section{Fem Gully Sandblow Site 96}

Site 96 consists of an intermittent stone artefact scatter within a relatively small (c. $100 \mathrm{~m} \times 80 \mathrm{~m}$ ) sandblow located some $100-120 \mathrm{~m}$ a.s.l. at the top of a steep erosion face some $2 \mathrm{~km}$ south of White Cliffs sandblow Site 98 . While no excavation or detailed survey work has been undertaken at the site, initial sample recording of artefacts $(n=49)$ indicated the presence of a variety of artefact forms (e.g. flakes, flaked pieces and cores) and the predominant use of silcrete $(38.8 \%)$ and sandstone (including arkose) (34.7\%) (McNiven 1984, 1985). Formal artefact types included silcrete and arkose beveledged tools and an edge-ground axe of volcanic stone (Figure 16).
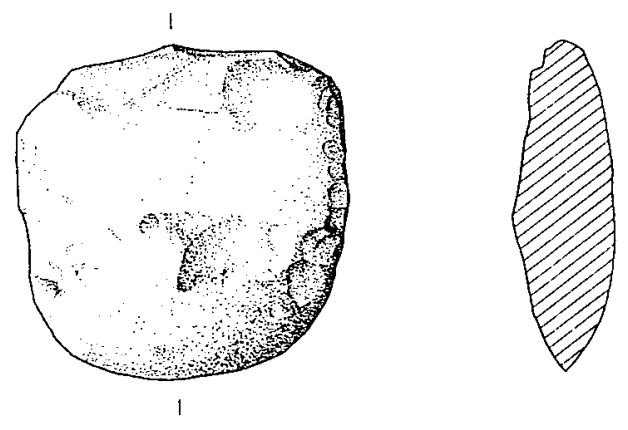

Figure 16: Edge-ground axe from Fem Gully sandblow Site 96 (IF2).

\section{Discussion}

\section{Model of sandblow site formation}

The four sites are located on the eastern half of large sandblows in an area of active sand erosion. I argue that these sites were created by the inland movement of Holocene sandblows through stone artefact deposits located on or immediately below the surface of a Pleistocene sand dune (McNiven 1985:26; cf. Lauer 1979:55-6). Details of this model are as follows (see also Thompson 1983; Thompson and Moore 1984).
1. a site with numerous stone artefacts is created on the surface of a vegetated Pleistocene dune, probably Dune System 4 (Figure 17a). The site may or may not be buried subsequently by sands deriving from Teewah Beach.

2. a sandblow forms between the coast and the stone artefact deposit (Figure 17b). The large deposit of sand forming the dune apex at the front of the sandblow (depicted in Figure 17) and trailing arms along both sides of the sandblow (not depicted in Figure 17) may consist of varying proportions of new sands derived from Teewah Beach and reworked Pleistocene sands derived from the floor of the sandblow.

3. the sandblow advances inland towards the stone artefact deposit and the slip-face at the front of the sandblow begins to bury (or further bury) part or all of the site (Figure 17c). It should be noted that at this stage, the entire sandblow may become stabilised and vegetated for a period of time. Eventually, however, another sandblow may follow the path of the old sandblow and pick up on the next stage of development.

4. the sandblow advances further inland and the dune apex subsequently re-exposes the stone artefact scatter as a deeply buried stratified site (cf. dune apex in-situ cultural layer at King's Bore sandblow Site 97). Stone artefacts erode out from the cultural layer and deflate down onto the dune floor as an exposed surface scatter (Figure 17d).

\section{Systemic site unity and chronology}

I argue that all four sandblow sites form part of a single system of sites for the following reasons. First, all sites are situated in identical geomorphological contexts on old Pleistocene dune deposits within active sandblows. Similar sites have not been found within sandblows which have failed to expose old Pleistocene dune deposits. Second, none of the sites exhibit humanly-derived faunal assemblages. Third, all stone artefact assemblages are dominated by silcrete along with quartz and/or arkose. Fourth, all sites exhibit one or more of the following implement types - bevel-edged tools, anvils and backed blades.

Establishing a chronological framework for this system of sites is limited by a lack of radiocarbon dates. At present, chronometric insights are limited to King's Bore sandblow Site 97 where an antiquity of between c. 3800 and $2300 \mathrm{cal} \mathrm{BP}$ was inferred. If the systemic unity model is correct, then White Cliffs sandblow Site 98, Cooloola Sand Patch Site 102 and Fern Gully sandblow Site 96 may have comparable ages.

Important corroborative evidence for the antiquity of these sites comes from Teewah Beach Site 26 located some $13 \mathrm{~km}$ south of Cooloola Sand Patch Site 102 (Figure 1). Recent excavations have revealed occupation dating between c. 5530 and $320 \mathrm{cal} \mathrm{BP}$, thus providing the oldest evidence for human use of the region (McNiven 1991a). While arkose was discarded in all 


\section{A MODEL OF SANDBLOW SITE FORMATION}

A

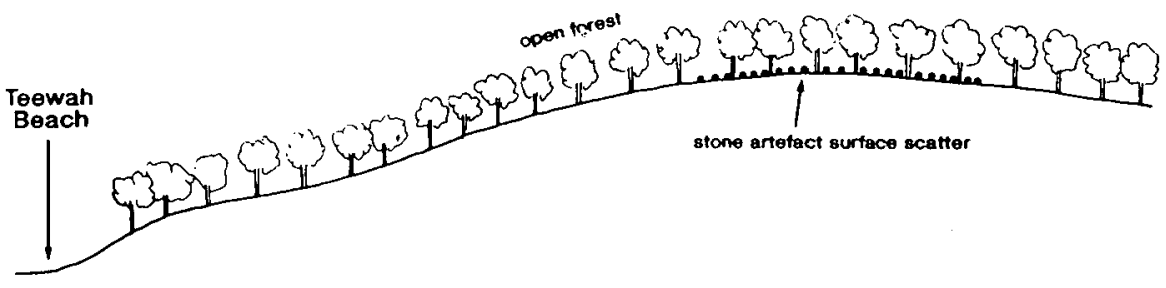

B

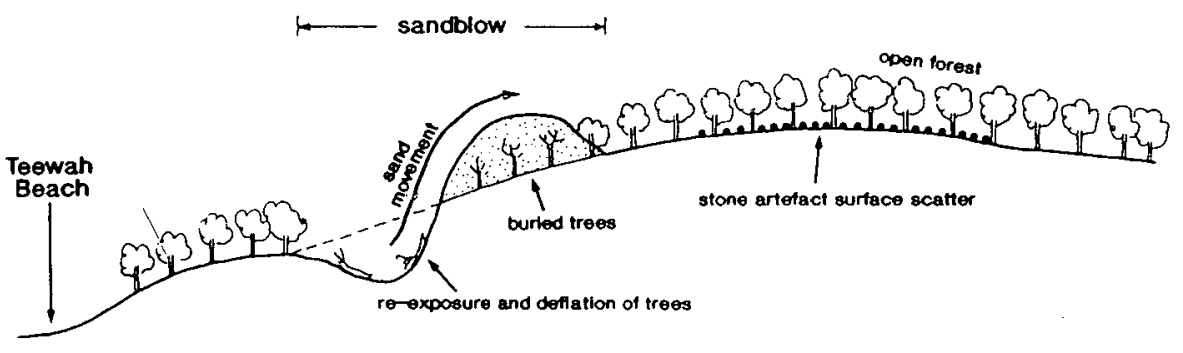

C

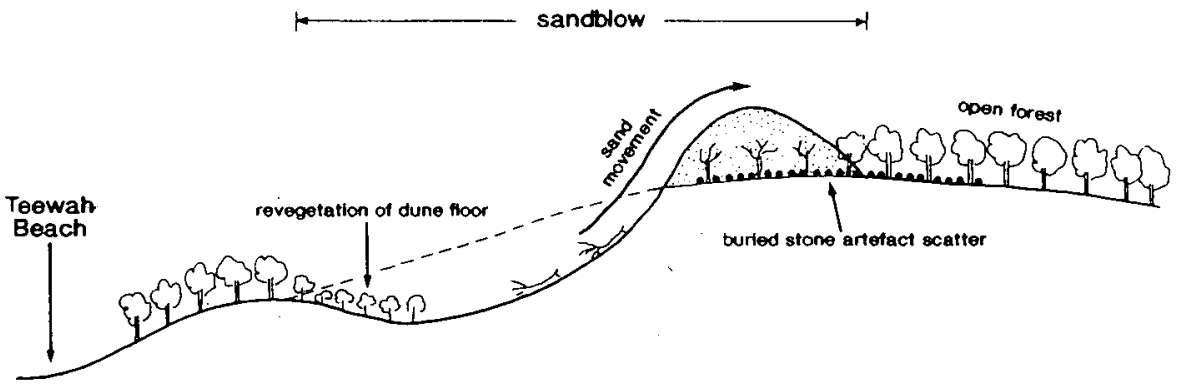

D

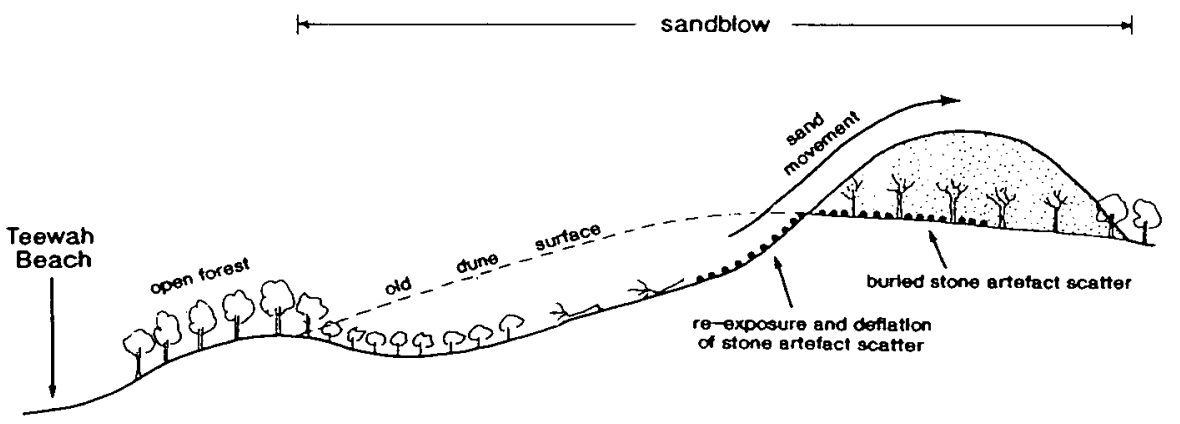

Figure 17: Model of sandblow site formation for Cooloola. 
levels of the site, silcrete discard was restricted mostly to levels dated between c. 5530 and 3360 cal BP. Similarly, a fragment of a bevel-edged tool was recovered from within this silcrete-rich zone (McNiven 1991a, 1992b). As silcrete is extremely rare on all other sites (i.e. middens) across eastern Cooloola which date to the last 900 years, I suggest that all sandblow sites discussed above, along with the lower levels of Teewah Beach Site 26, represent varying spatial and chronological components of a single Early Phase spanning at least 5500-2300 cal BP.

\section{Settlement-subsistence activities}

All sandblow sites were recorded across eastern Cooloola within $2 \mathrm{~km}$ of Teewah Beach. Although large sections of Cooloola east of the Noosa River exhibit potential site locations in the form of Pleistocene dunes (e.g. Dune Systems 4-6), intensive surveying of these areas resulted only in the location of recent ( $<900 \mathrm{BP}$ ) shell middens (see McNiven 1990a for details). I suggest, therefore, that a bias existed towards the location of Early Phase sites across eastern Cooloola in areas within close proximity to Teewah Beach.

While the study of Early Phase subsistence activities associated with sandblow sites is severely limited by a lack of faunal and floral remains, indirect evidence supports exploitation of rainforest and marine resources. For example, although the mammal resource base of the sandmass is generally poor, rainforests currently exhibit relatively more ringtail possums (Pseudocheirus peregrinus), brushtail possums (Trichosurus caninus) and long-nosed bandicoots (Perameles nasuta). The only other relatively abundant mammals across the sandmass are rodents (e.g. fawn-footed melomys, Melomys cervinipes) and bats (e.g. Queensland blossom bat, Syconycteris australis) (Dwyer, Hockings and Wilmer 1979; Dwyer, Kikkawa and Ingram 1979). Rainforests also exhibit the highest concentration of plant foods on the sandmass. More common species include fern roots (Blechnum spp.), cycads (Macrozamia miquelii) and yams (e.g. Dioscorea transversa) (McNiven 1992a:499-500).

Along the adjacent shores of Teewah Beach is found a rich suite of marine shellfish and fish resources of even greater size and accessibility compared to rainforest faunal resources. Significant among these are large colonies of pipi (Donax deltoides) shellfish found along the sandy beach and a variety of fish species including large schools of tailor (Pomatomus saltatrix), bream (A canthopagrus australis), tarwhine (Rhabdosargus sarba) and whiting (Sillago spp.).

Early Phase stone artefacts are consistent with the rainforest exploitation hypothesis. For example, recent use-wear and residue analyses of bevel-edged tools similar to those recovered from Early Phase sites at Cooloola strongly support a function associated with plant foods, in particular Blechnum indicum root preparation (Gillieson and Hall 1982; Hall et al. 1989; Higgins 1988; Kamminga 1981; McNiven 1992b).

One implication of this possible subsistence focus on rainforest (especially plant) and marine (especially animal) resources is the biased location of Early Phase sandblow sites along the eastern periphery of Cooloola. All of these sites are situated optimally between large areas of rainforest to the west and the sea to the east.

\section{Fraser Island sandblow sites}

The archaeological record of eastern Fraser Island is also characterised by shell middens along the coastal fringe and a series of stone artefact scatter sites devoid of faunal remains situated within large sandblows located a little further inland (Lauer 1977, 1979). Although no information is provided concerning raw material differences between midden and sandblow sites, and aspects of Lauer's artefact typology are problematic (e.g. McNiven 1993a; McNiven and Hiscock 1988), I suggest that the Fraser Island sandblow sites are analogous to Early Phase sandblow sites at Cooloola. That is, they represent the remains of a pre-midden phase settlementsubsistence system focused upon the exploitation of rainforest and marine resources.

Application of the Cooloola Early Phase sandblow model to Fraser Island sandblow sites contrasts markedly with Lauer's (1979) inferences concerning the contemporaneity of these sites with recent (late Holocene) shell midden sites. He argues that sandblow "campsites" are functionally complementary to midden sites strategically located along the adjacent coast. Regarding, "the curious location" of these sites "in open unvegetated and loose sand, completely at the mercy of the elements", Lauer (1979:55-65) suggests an anthropogenic origin for sandblow formation and vegetation denudation resulting from Aboriginal fires and firewood collection. On the contrary, I suggest the location of these sites within sandblows simply results from the chance movement of a recent sandblow through an older stone artefact scatter (see McNiven 1985:26).

\section{Early Phase termination and rainforest diminution}

I have argued elsewhere that the commencement of Early Phase occupation of Cooloola resulted from the localised adaptation of an existing coastal settlement-subsistence system which had been following the transgressing coastline westwards until its relative stabilisation at c.6000 BP (McNiven 1991a). Sometime after c.3000 BP, however, I believe Early Phase lifeways on the sandmass were transformed largely in response to climatically induced changes in rainforest resources. For example, between 6000-3000 BP, wetter and warmer climatic conditions across eastern Australia (Bowler et al. 1976:385; Hooley et al. 1980:360; Kershaw 1975:185; 1980:34) would have been favourable for an expansion of rainforest areas (Bowler et al. 1976:385; Kershaw $1975: 185 ; 1980: 34)$. In contrast, the last 3000 years saw the onset of drier conditions (Bowler et al. 1976:390; Head 1986:124; 1988:44; Hooley et al. 1980:360; Kershaw 1975:18j; 1980:34; 1981a; 1981b:92; Ross 1981:152) resulting in a diminution of rainforest areas (Kershaw 1975:185; 1980:34). This process possibly 
was compounded by an increase in fire activity (Kershaw 1975:187; Hooley et al. 1980:360) which may have had an anthropogenic origin (Bowdler 1988:49; Kershaw 1981:74; Lourandos 1988:283). In this connection, it is interesting to note that massive deposits of silts across western Moreton Bay dating to the last 3000 years appear to derive largely from the Brisbane River and its hinterland catchments (Hekel et al. 1979:17). While reasons for both increased erosion of hinterland areas and riverine silt loads remain problematic (Hekel et al. 1979:17-8), Walters (1989:222) advances a highly plausible hypothesis for vegetation disturbance resulting from Aboriginal burning activities.

The significant effects that climate and fires may have had on the areal extent of rainforest patches at Cooloola after 3000 years ago would have been greatly exacerbated by a major period of sand dune development (Dune Systems 1-3) across eastern Cooloola commencing 4000-3000 BP (Thompson 1983:209). Given these dunes covered large sections of Dune System 4 which presently support almost all of the rainforest on the sandmass, it is probable that they similarly buried large tracts of rainforest in their path (Figure 1).

\section{Rainforest and culture change in the SE Queensland hinterland}

The combined effects of climate, fire and dune development would have had a major impact on the potential rainforest resource base of the Great Sandy Region in the period after $3000 \mathrm{cal}$ BP. In a similar way, it is likely that the extent of rainforest resources in other parts of southeast Queensland would have been reduced. It can be expected, therefore, that in some areas diminution of important rainforest resource patches may have reached a critical threshold sometime between 3000 and 2000 cal BP beyond which existing settlementsubsistence arrangements could continue. Such disruption may have stimulated a restructuring of settlementsubsistence activities to incorporate, among other things, more intensive exploitation of remaining rainforest patches in some areas and decreased use of rainforest resources in other areas. With respect to Cooloola I suggest that people responded by decreasing their use of this region, at least in the short term, and increasing their use of hinterland areas. For example, essentially all of the cultural remains excavated from Cooloola date from c. 5500-2300 cal BP (Early Phase sites) or c. 900-100 cal - BP (Recent Phase midden sites). In contrast, c. $2800 \mathrm{cal}$ BP marks the commencement of major occupation and rainforest faunal and floral exploitation at Brooyar Rockshelter located in the hinterland some $30 \mathrm{~km}$ west of Cooloola (McNiven 1988). Whether or not commencement of use of this site reflects in any way changes in land-use patterns on the adjacent coast remains to be seen. The central point is that a major restructuring of land-use patterns may have occurred in the greater region largely in response to a restructuring of important resources, in particular those derived from rainforests.

Similar changes have been observed in other hinterland areas of southeast Queensland. In the Lamington Plateau region close to the New South Wales border, Aboriginal people appear to have responded by increasing their exploitation of remaining rainforest resources. Excavations at Bushranger's Cave for example have revealed continuous exploitation of sub-coastal rainforest resources for at least 6000 years (Hall 1986). Hiscock and Hall (1988:101-2) and Mowat (1989:69) note, however, an increase in the discard of faunal remains after c. 2500 cal BP. Given that the range of exploited taxa "exhibits a remarkable consistency throughout the past 6000 years" (Hall 1986:98), Hiscock and Hall (1988:101) state that "the increase in faunal discard rates" may simply represent "more intensive food processing activities rather than an alteration to hunting strategies" (see also Mowat 1989). The timing of this increase in rainforest resource exploitation also coincides with the commencement of occupation at Bishop's Peak Rockshelter located less than $20 \mathrm{~km}$ from Bushranger's Cave. This shelter similarly exhibits a range of rainforest faunal species and a basal date of c. 2700 cal BP (Edmonds 1986; Hall and Hiscock 1988a:19). Further to the northwest at Gatton Shelter, Morwood (1986) documents a major increase in the discard of stone artefacts and faunal remains after c.3200 cal BP, following initial site occupation some c. 4200 cal BP (Hall and Hiscock 1988a:19). Although the faunal assemblage consists of animals from a variety of environmental settings, the bulk is made up of species whose habitat includes rainforest.

An alternative response to any decrease in the potential of rainforest resources for exploitation is shown at Platypus Rockshelter located along the Brisbane River. The site produced a basal date of c.5300 cal BP and is associated with a range of fauna, much of it derived from riverine rainforest communities (Novello 1989). After c. 2400 cal BP, however, there exists a dramatic decrease in bone remains which Hall and Hiscock (1988b:49) interpret as "a genuine reduction of the discard of bone within the shelter". This pattern has been confirmed by a recent taphonomic analysis of faunal remains from the site (Novello 1989).

From this review it appears that changes coinciding with the end of Early Phase occupation of the Cooloola sandmass are reflected also at other sites in southeast Queensland associated with rainforest exploitation. It is important to note, however, that changes occurring at this time may not all be related to changes in environment. For example, I have noted elsewhere that the appearance of tula adzes and bifacial points in southeast Queensland some 3000 years ago may indicate the development of inter-regional social linkages with southern central Queensland reminiscent of historically recorded Bunya gatherings (McNiven 1993b). Whether or not these suggested changes in social relations had any effect upon changes in local settlement-subsistence activities associated with rainforest exploitation, or vice-versa, is a question for the future (see Morwood 1987). At present, available evidence suggests that the restructuring of 
Aboriginal rainforest settlement-subsistence activities across southeast Queensland some $3000-2000$ cal BP was highly variable and complex, possibly involving regionally specific thresholds and tolerances to environmental change.

\section{Conclusion}

In this paper I have suggested that the restructuring of rainforest settlement-subsistence activities across selected parts of southeast Queensland some 3000-2000 years ago can be traced in increased use of some areas and decreased use of others. Such an inference has major implications concerning notions of population change and intensity of resource use. For example, it is possible that recent statements concerning late Holocene increases in population and intensity of resource extraction across southeast Queensland by Hall and Hiscock (1988a) and Morwood $(1986,1987)$ are premature due to an analytical bias towards sites exhibiting increased discard of faunal and/or stone artefactual remains. Inferences concerning periods of decreased rainforest use across the Great Sandy Region and at Platypus Rockshelter, however, suggest that changes in resource use intensity at sites may be regionally or even site specific. As a result, simple comparisons between a limited number of sites in differing regions may be quite misleading and gloss over small-scale responses in land-use patterns (see Bird and Frankel 1991a, 1991b).

The notion of regionally specific changes in land-use patterns across eastern Australia during the late Holocene has also been discussed by Hiscock (1986). In response to Lourandos' $(1983 ;$ 1985) notion of late Holocene "intensification", Hiscock notes that no single trend exists towards either intensification or de-intensification of settlement-subsistence activities. In contrast, both trends, particularly with regard to changes in site numbers and cultural discard, may occur at an inter-regional and intraregional scale. A good example of the latter exists in the lower southeast of South Australia. Here Luebbers (1978) documents a major spatial change in midden formation from inland swamps to the coastal fringe around $2000 \mathrm{BP}$. He argues that such "substantial changes in the regional demographic structure" were in response to "a major reduction in swampside resources" brought about by drier climatic conditions commencing some 3000 BP (1978:308). Whether or not this settlement restructuring was also a response to changes in social relations analogous to those suggested for adjacent areas of southern Australia some 3000-2000 years ago is unknown (Flood et al. 19877; Lourandos 1983). In this regard, synchronous changes in settlement-subsistence activities across northwestern Tasmanian which has been socially isolated from the mainland for c. 8,000 years (Blom 1988:96) suggest responses to more pervasive climatic changes are at play across the Bassian divide (see Bowdler 1988; Bowdler and Lourandos 1982; Lourandos 1988; Sutton 1985). Similarly, abandonment of nearby Kangaroo Island c. 2500 years ago which has a large area of some $4400 \mathrm{~km}^{2}$ is associated with climatically induced changes in resource availability (Lampert 1981).

The most extreme application of the complementary response model to changes in coastal and near coastal resource distribution would have been around the time of the Postglacial Marine Transgression. The effects of rainforest and swamp diminution discussed above would have been only minor compared to the massive effects of rising sea levels upon terrestrial coastal and hinterland resources across the continental shelf. As Flood (1989:189) notes, 'about one seventh of the landmass of Greater Australia - two and a half million square kilometres - was inundated by rising glacial melt-water". While it is beyond the scope of this paper to elaborate upon human responses to these conditions across Australia, I do want to make the point that the evidence for increased use of the east coast during the last 6000 years was complementary to decreased use of the drowned continental shelf. As a result, notions of coastal intensification during this period (vis-a-vis the Pleistocene) may be entirely spurious until better understanding is gained on the nature of Pleistocene coastal settlement-subsistence activities. However, such criticisms do not deny in any way late Holocene increases in occupational intensity and social complexity (cf. Barker 1991; Lourandos 1985; McNiven 1991a).

It is hoped that the complementary response model followed in this paper continues to be addressed by investigators concerned with changes in Aboriginal landuse pattens. Central to this approach is detailed documentation of chronological and spatial variations in settlement-subsistence activities within and between regions (see Bird and Frankel 1991a, 1991b). It is only when general understanding is gained into how given settlement-subsistence systems (as opposed to a few site specific parts there of) respond to changes in environmental and/or social conditions that higher order inferences such as those concerning intensification and population increase across eastern Australia during the Holocene can suitably be addressed (Dodson et al. 1992).

\section{Acknowledgments}

Helpful criticisms of earlier drafts of this paper were provided by Sarah Colley, David Frankel, Clive Gamble, Jay Hall, Ian Lilley and Peter White. All errors in fact or interpretation are my responsibility.

\section{References Cited}

Barker, B.C. 1991 Nara Inlet 1: coastal resource use and the Holocene marine transgression in the Whitsunday Islands, central Queensland. A rchaeology in Oceania 26(3):102-9.

Barry, D.H. and P.R. Campbell 1977 A survey of the mammals and herptiles of Fraser Island, with comments on the Cooloola peninsula, North Stradbroke, Moreton and Bribie Islands. University of Queensland, Anthnopology Museum, Occasional Papers in Anthropology 8:147-77. 
Bird, C.F.M. and D. Frankel 1991 a Chronology and explanation in western Victoria and south-east South Australia. A rchaeology in Oceania 26(1):1-16.

Bird, C.F.M. and D. Frankel $1991 \mathrm{~b}$ Problems in constructing a prehistoric regional sequence: Holocene Southeast Australia. World Archaeology 23(2):179-92.

Blom, W.M. 1988 Late Quaternary sediments and sealevels in Bass Basin, southeastern Australia - a preliminary report. Search 19(2):94-6.

Bowler, J., G.S. Hope, J.N. Jennings, G. Singh and D. Walker 1976 Late Quaternary climates of Australia and New Guinea. Quatemary Research 6:359-94.

Bowdler, S. 1988 Tasmanian Aborigines in the Hunter Islands in the Holocene: island resource use and seasonality. In G. Bailey and J. Parkington (eds) The archaeology of prehistoric coastlines. Pp.42-52. Cambridge: Cambridge University Press.

Bowdler, S. and H. Lourandos 1982 Both sides of Bass Strait. In S. Bowdler (ed.) Coastal archaeology in eastem A ustralia. Pp.121-32. Canberra: Department of Prehistory, Research School of Pacific Studies, The Australian National University.

Department of Forestry 1979 Fraser Island, central sheet, edition 1, 1:50,000. Brisbane: Government Printing Office.

Department of Forestry 1985 Fraser Island, south sheet, edition 2, 1:50,000. Brisbane: Government Printing Office.

Department of Forestry 1986 Womalah State Forest and part of the Cooloola National Park, edition 1, 1:25,000. Brisbane: Government Printer.

Dodson, J., R. Fullagar and L. Head 1992 Dynamics of environment and people in the forested crescents of temperate Australia. In J. Dodson (ed.) The naive lands: prehistory and environmental change in A ustralia and the south-west Pacific. Pp.115-59. Melbourne: Longman Cheshire.

Dwyer, P.D., M. Hockings and J. Willmer 1979 Mammals of Cooloola and Beerwah. Proceedings of the Royal Society of Queensland 90:65-84.

Dwyer, P.D., J. Kikkawa and G.J. Ingram 1979 Habitat relations of vertebrates in subtropical heathlands of coastal southeastem Queensland. In R.L. Specht (ed.) Ecosystems of the World $9 A$ Heathlands and related scrublands. Descriptive studies. Pp.281-99. Amsterdam: Elsevier Scientific Publishing Co.

Edmonds, V.J. 1986 Subtropical rainforest: archaeological evidence of Aboriginal use in the border ranges, southeast Queensland. Unpublished Master of Letters thesis, University of New England.

Flood, J., B. David, J. Magee and B. English 1987 Birrigai: a Pleistocene site in the south-eastern highlands. A rchaeology in Oceania 22(1):9-26.

Flood, J.M. 1989 Archaeology of the Dreamtime. Sydney: Collins.

Gillieson, D.S. and J. Hall 1982 Bevelling bungwall bashers: a use-wear study from southeast Queensland. A ustralian A rchaeology 14:43-61.
Hall, J. 1986 Exploratory excavation at Bushrangeı s Cave (site LA:A11), a 6000 year old campsite in southeast Queensland: preliminary results. A ustralian A rchaeology 22:88-103.

Hall, J., S. Higgins and R. Fullagar 1989 Plant residues on stone tools. In W. Beck, A. Clarke and L. Head (eds) Plants and A ustralian archaeology. Pp.136-60. Tempus Volume 1. Anthropology Museum, University of Queensland.

Hall, J. and P. Hiscock 1988a The Moreton Region Archaeological Project (MRAP) - Stage 11: an outline of objectives and methods. Queensland A rchaeological Research 5:4-24.

Hall, J. and P. Hiscock 1988b Platypus Rockshelter (KB:A70), S.E. Queensland: chronological changes in site use. Queensland A rchaeological Research 5:4262.

Harrold, A.G., W.J.F. McDonald, M.S. Hopkins, J. Walker, C.S. Sandercoe and C.H. Thompson 1987 Studies in landscape dynamics in the Cooloola-Noosa River area, Queensland. 5. Vascular plants. CSIRO Division of Soils, Divisional Report No. 89.

Head, L. 1986 Palaeoecological contributions to Australian prehistory. A rchaeology in Oceania 21(2): 121-29.

Head, L. 1988 Holocene vegetation, fire and environmental history of the Discovery Bay region, south-western Victoria. Australian Joumal of Ecology 13:21-49.

Hekel, H., W.T. Ward, M. Jones and D.E. Searle 1979 Geographical development of northern Moreton Bay. In A. Bailey and N.C. Stevens (eds) Northern Moreton Bay symposium. Pp.7-18. Brisbane: Royal Society of Queensland.

Higgins, S. 1988 Starch grain differentiation of archaeological residues: a feasibility study. Unpublished B.A. (Hons) thesis, University of Queensland.

Hiscock, P. 1984 Preliminary report on the stone artefacts from Colless Creek Cave, northwest Queensland. Queensland Archaeological Research 1:120-51.

Hiscock, P. 1986 Technological change in the Hunter River Valley and its implications for the interpretation of late Holocene change in Australia. A rchaeology in Oceania 21(1):40-50.

Hiscock, P. and J. Hall 1988 Technological change at Bushranger's Cave (LA:Al1), S.E. Queensland. Queensland A rchaeological Research 5:90-112.

Hooley, A.D., W. Southem and A.P. Kershaw 1980 Holocene vegetation and environments of Sperm Whale Head, Victoria, Australia. Journal of Biogeography 7:349-62.

Kamminga, J. 1981 The bevelled pounder: an Aboriginal stone tool type from southeast Queensland. Proceedings of the Royal Society of Queensland 92:31-5.

Kershaw, A.P. 1975 Late Quaternary vegetation and climate in northeastern Australia. In R.P. Suggate 
and M.M. Cresswell (eds) Quaternary Studies. Pp.181-87. Wellington: The Royal Society of New Zealand.

Kershaw, P. 1980 Long term changes in north-east Queensland rain forest. In J. Wright, N. Mitchell and $\mathrm{P}$. Watling (eds.) Reef rainforest mangroves man. $\mathrm{Pp}$. 37-40. Cairns: Wildlife Preservation Society of Queensland.

Kershaw, P. 1981a Palynology at Monash. A ustralian A rchaeology 12:71-78.

Kershaw, P. 1981b Quaternary vegetation and environments. In A. Keast (ed.) Ecological biogeography of Australia Pp.81-101. The Hague: Junk.

Lampert, R. 1981 The great Kartan mystery. Terra Australia 5. Canberra: Department of Prehistory, Research School of Pacific Studies, Australian National University.

Lauer, P.K. 1977 Report of a preliminary ethnohistorical and archaeological survey of Fraser Island. University of Queensland, Anthropology Museum, Occasional Papers in Anthropology 8:1-38.

Lauer, P.K. 1979 The museum's role in field work: the Fraser Island study. University of Queensland, Anthropology Museum, Occasional Papers in Anthropology 9:31-72.

Lourandos, H. 1983 Intensification: a late PleistoceneHolocene archaeological sequence from southwestern Victoria. A rchaeology in Oceania 18(2):81-94.

Lourandos, H. 1985 Intensification and Australian prehistory. In T.D. Price and J. Brown (eds) Prehistoric hunter-gatherers: the emengence of cultural complexity Pp.385-423. Orlando: Academic Press.

Lourandos, H. 1988 Seals, sedentism and change in the Bass Strait. In B. Meehan and R. Jones (eds) Archaeology with ethnography: an Australian perspective. Pp.277-85. Canberra: Department of Prehistory, Research School of Pacific Studies, The Australian National University.

Luebbers, R.A. 1978 Meals and menus: a study of change in prehistoric coastal settlements in South Australia. Unpublished Ph.D thesis, Australian National University

McNiven, I. 1984 Initiating archaeological research in the Cooloola region, southeast Queensland. Unpublished B.A. (Hons) thesis, University of Queensland.

McNiven, I. 1985 An archaeological survey of the Cooloola region S.E. Queensland. Queensland Archaeological Research. 2:4-37.

McNiven, I. 1988 Brooyar Rockshelter: a late Holocene seasonal hunting camp from S.E. Queensland. Queensland Archaeological Research 5:133-60.

McNiven, I. 1990a Prehistoric Aboriginal settlement and subsistence in the Cooloola region, coastal southeast Queensland. Unpublished Ph.D thesis, The University of Queensland.

McNiven, I. - 1990b Blowout taphonomy: non-cultural associations between faunal and stone artefact assemblages along the Cooloola coast, southeast Queensland. A ustralian Archaeology. 31:67-74.

McNiven, I. 1991a Teewah Beach: new evidence for Holocene coastal occupation in southeast Queensland. A ustralian A rchaeology 33:14-27.

McNiven, I. 1991b Settlement and subsistence activities along Tin Can Bay, southeast Queensland. Queensland A rchaeological Research 8:85-107.

McNiven, I. 1992a Shell middens and mobility: the use of off-site faunal remains, Queensland, Australia. Joumal of Field A rchaeology 19(4):495-508.

McNiven, I. 1992b Bevel-edged tools from coastal southeast Queensland. Antiquity 66(252):701-9.

McNiven, I. 1993a Corroboree Beach, Fraser Island: archaeological survey and management recommendations. Volume 1. Report. Unpublished report, Queensland Department of Environment and Heritage, Maryborough.

McNiven, I. 1993b Tula adzes and bifacial points on the east coast of Australia. Australian Archaeology 36:22-33.

McNiven, I. and P. Hiscock 1988 Small unifacial pebble cores from Fraser Island, S.E. Queensland. Queensland A rchaeological Research 5:161-65.

Morwood, M.J. 1986 The archaeology of art: excavations at Maidenwell and Gatton shelters, southeast Queensland. Queensland Archaeological Research 3:88-132.

Morwood, M.J. 1987 The archaeology of social complexity in south-east Queensland. Proceedings of the Prehistoric Society 53:337-50.

Mowat, F. 1989 Bushranger's Cave: a faunal analysis. Unpublished B.A. (Hons) thesis, The University of Queensland.

Novello, M. 1989 A taphonomic analysis of the faunal remains from Platypus Rockshelter (KB:A7O), southeast Queensland. Unpublished B.A. (Hons) thesis, The University of Queensland.

Report 1991 Commission of Inquiry into the Conservation, Management and Use of Fraser Island and the Great Sandy Region. Brisbane: Queensland Government Printer.

Ross, A. 1981 Holocene environments and prehistoric site patterning in the Victorian Mallee. A rchaeology in Oceania 16(3):145-55.

Sinclair, J. 1990 Draft nomination of the Great Sandy Region for listing on the World Heritage. Fraser Island Defenders Organisation, Gladesville. New South Wales.

Stanton, J. 1977 Landscape classification on Fraser Island. University of Queensland, Anthropology Museum, Occasional Papers in Anthropology 8:127. 33.

Struiver, M. and P.J. Reimer 1986 A computer program for radiocarbion age calibration Radiocarbon 28: 1022-30.

Sutton, S.A. 1985 Warragarra stone: a technological analysis of a stone artefact assemblage from central 
Tasmania. Unpublished BA (Hons) thesis, University of New England.

Tejan-Kella, M.S., D.J. Chittleborough, R.W. Fitzpatrick, C.H. Thompson, J.R. Prescott and J.T. Hutton 1990 Thermoluminescence dating of coastal sand dunes at Cooloola and North Stradbroke Island, Australia. A ustralian Joumal of Soil Research 28:465-81.

Thompson, C.H. 1981 Podzol chronosequences on coastal dunes of eastern Australia. Nature 291:59-61.

Thompson, C.H. 1983 Development and weathering of large parabolic dune systems along the subtropical coast of eastern Australia. Geomorphologie suppl. Bull. 45:205-25.

Thompson, C.H. and A.W. Moore 1984 Studies in landscape dynamics in the Cooloola-Noosa area, Queensland. 1. Introduction, general description and research approach. CSIRO Division of Soils, Divisional Report No. 73.
' Walker, J., C.H. Thompson, I.F. Fergus and B.R. Tunstall 1981 Plant succession and soil development in coastal sand dunes of subtropical eastern Australia. In H. Shugart, D. Botkin and D. West (eds) Forest succession: concepts and application. Pp.107-31. New York: Springer-Verlag.

Walters, I. 1989 Intensified fishery production at Moreton Bay, southeast Queensland, the late Holocene. Antiquity 63:215-24.

Webb, L.J. and J.G. Tracey 1975 The Cooloola rainforest. Proceedings of the Ecological Society of A ustralia 9:317-20.

Ian McNiven Queensland Department of Environment and Heritage Central Coast Regional Centre Maryborough Qld 4650 